\title{
PROMOTION OF SUSTAINABLE AGRICULTURE BY MPUMALANGA AGRICULTURAL EXTENSION SERVICES: PERSPECTIVE OF PUBLIC EXTENSION PRATICTIONERS
}

\author{
Khwidzhili R.H. ${ }^{1}$ and Worth S. ${ }^{2}$ \\ Correspondence author: R.H. Khwidzhili. Email: humphrey.khwidzhili@ump.ac.za
}

\begin{abstract}
The ever-growing population of the world compels most farmers to resort to farming practices that are unsustainable. This is particularly true in Mpumalanga Province, where there is a lack of support towards promoting sustainable agriculture. This study evaluates the role of public agricultural extension in promoting sustainable agriculture in the Mpumalanga Province of South Africa. The role of public agricultural extension is evaluated against the framework of the five pillars of sustainable agriculture. The study evaluates the context of dominant agricultural extension approaches used in Mpumalanga Province. Data were collected through questionnaires with 68 respondents, comprising of various extension practitioners in all 17 districts in Mpumalanga Province. The study provides an analytical emphasis that assessment of farmers' livelihood will assist extension practitioners to programme their interventions based on farmers' needs. The study further evaluates extension practitioners' knowledge towards the concept of sustainable agriculture. The support provided to extension practitioners in promoting sustainable agriculture was also appraised. The results of the study present empirical consolidated responses on extension practitioners' knowledge of the five pillars of sustainable agriculture. Finally, extension practitioners provided their suggestions on what measures could be taken to promote sustainable agriculture in Mpumalanga Province. Drawing from the results of this study, it is evident that there is a need for frameworks and support for extension practitioners towards promoting sustainable agricultural practices.
\end{abstract}

Keywords: Extension practitioners, Five pillars, Mpumalanga Province, Natural environment, Sustainable agriculture

\section{INTRODUCTION}

Although there is gradual changes in this figure, about $60 \%$ of the land in Mpumalanga is used for agricultural purposes. Mpumalanga is one of the nine provinces in South Africa. The name Mpumalanga means east or literally the place where the sun rises. Mpumalanga lies in the eastern part of South Africa and shares borders with two other African countries, namely Mozambique and the Kingdom of eSwatini (Swaziland). The province also share borders with other South African provinces which includes Limpopo to the north, Gauteng to the west, the Free State to the south west, and Kwa-Zulu Natal to the south. The province is divided into four district municipalities, namely Ehlanzeni, Bohlabela, Nkangala, and Gert Sibande. The province is further sub-divided into 17 local municipalities which are Albert Luthuli,

\footnotetext{
${ }^{1}$ R.H. Khwidzhili. PhD Student at the University of KwaZulu-Natal and Lecturer: Agricultural Extension and Rural Resource Management, University of Mpumalanga, P/Bag x 11283, Nelspruit, 1200. Tel. 0130020144 ; E mail: humphrey.khwidzhili@ump.ac.za. Orcid 000-00021964-1102

${ }^{2}$ Prof. S.Worth. Programme coordinator: Agricultural Extension and Rural Resource Management, School of Agriculture, Earth and Environmental Sciences. University of Kwa-Zulu Natal, P/Bag x01, Scottsville, 3209. Tel. 033260 5811; E mail worth@ukzn.ac.za, Orcid 0000-0002-3291-5542
} 
Depaliseng, Goven Mbeki, Lekwa, Mkhondo, Msukalikwa, Pixley ka Seme, Delmas, Dr. JS Moroka, Emalahleni, Highlands, Steve Tshwete, Thembisile Hani, Bushbuckridge, Nkomazi, Thaba Chweu, and Mbombela which also includes Umjindi.

In each of the 17 local municipalities, four extension practitioners were interviewed. Thus, 68 extension practitioners formed part of the sample. A number of farmers were also interviewed throughout Mpumalanga in order to triangulate the validity of data collected from extension practitioners. The study provides a perspective of some common extension approaches that are used in Mpumalanga Province. This study outlines the imperative for considering farmers' livelihood prior to providing extension services. The argument for considering livelihood is based on the fact that farmers differ in terms of their well-being which is related to income, education, experience, and other determining baselines.

Some respondents were quoted, meaning that their exact wording was extracted either from audio recordings or questionnaires. The study assessed the respondents' knowledge with regards to the concept of sustainable agriculture. It became somewhat clear that their knowledge was especially based on three pillars of sustainable agriculture, namely social, environmental and economic viability (Khwidzhili \& Worth, 2019; Tey et al, 2012) instead of the total five pillared framework (Khwidzhili \& Worth, 2016). The study provides a perspective of the respondents towards promoting sustainable agriculture in Mpumalanga Province. It further assesses the support given to extension practitioners towards promoting sustainable agricultural practices. The empirical perspectives of farmers towards sustainable agricultural practices were also highlighted. Finally, some initiatives for promoting sustainable agriculture in Mpumalanga were also outlined. The study concludes by providing philosophical conclusions and recommendations based on the results of this study.

\section{OBJECTIVES AND PURPOSE OF THE STUDY}

The main objective of the study is to evaluate the promotion of sustainable agriculture by Mpumalanga public agricultural extension practitioners. The study evaluates whether current agricultural extension services are aligned to the five pillars of sustainable agriculture. The study further evaluates whether extension practitioners have support towards promoting sustainable agricultural practices in Mpumalanga Province. It also highlights the reaction of farmers towards sustainable agriculture. The study finally draws from public agricultural extension practitioners on what could be initiated to promote sustainable agriculture in Mpumalanga Province. The purpose of the study was to create awareness about the five pillared framework within the Mpumalanga Department of Agriculture, Rural Development and Land Administration.

\section{METHOD}

Data was collected through semi-structured questionnaires with 68 public agricultural extension practitioners in Mpumalanga Province. Mpumalanga consists of 17 municipalities. In each municipality, four extension practitioners were purposively selected to take part in this study. The researcher arranged with extension managers of all 17 municipalities for the purpose of collecting data. According to Silverman (2010), purposive sampling allows for selecting rich information from respondents with specific characteristics relevant to the objectives of the research. Purposive sampling enables the researcher to select a case as it demonstrates some characteristic or process such as that which the research is interested in (Cohen, Manion \& 
Morrison, 2007). The selection considered gender, age, experience, and qualification of the respondents. The study adopted a basic qualitative approach. The research drew its methods from the interpretivist paradigm (Nieuwenhuis, 2007). The interpretivist paradigm focuses on relevant experiences and interpretation.

Table 1 presents consolidated responses of all sixty eight respondents. The subdivision on the five pillars of sustainable agriculture in Table 1 was categorized by the researcher and not by individual respondents. The researcher classified the sustainability indicators in Table 1 according to five pillared framework.

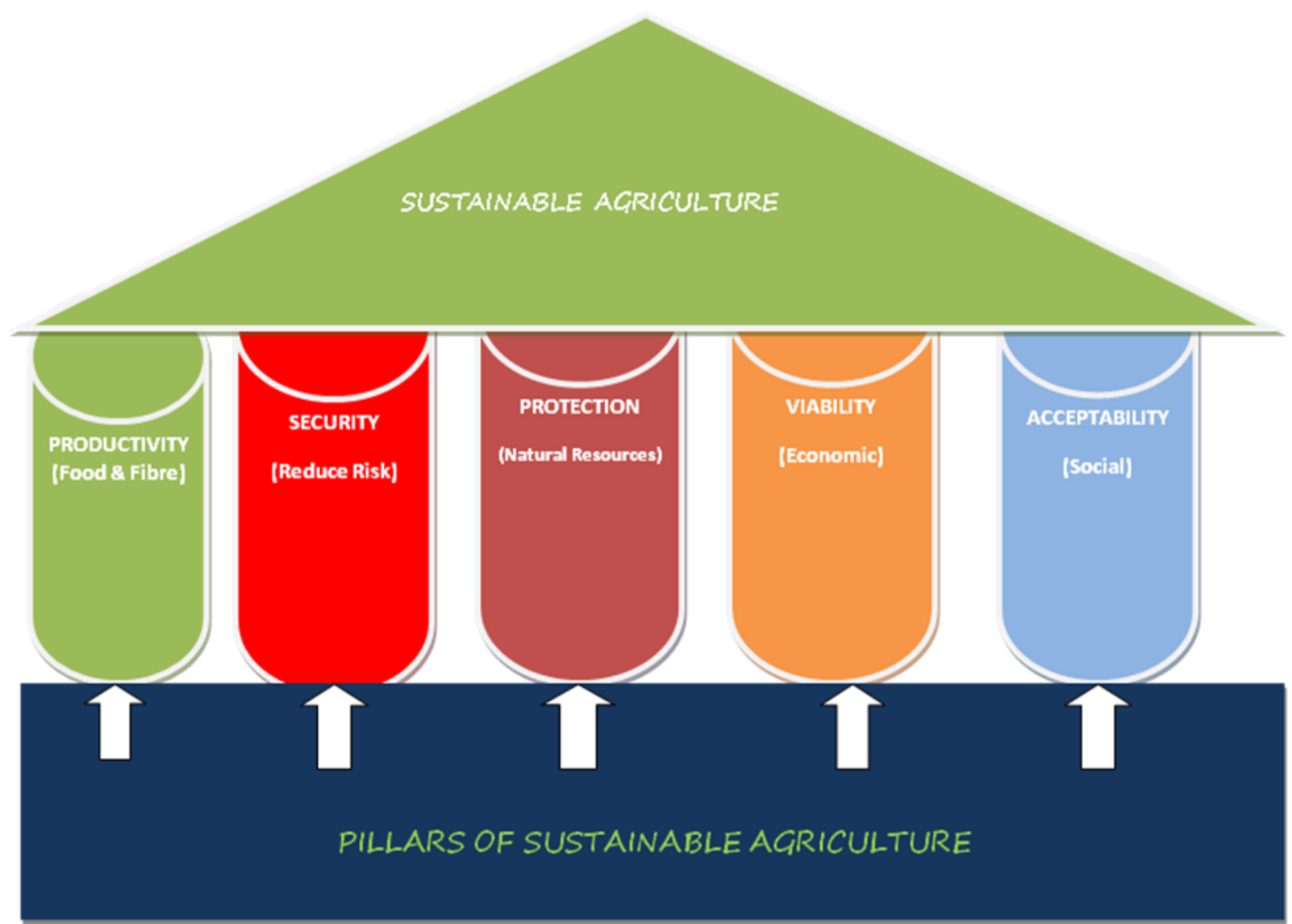

Figure 1: Five pillars of sustainable agriculture (Khwidzhili \& Worth, 2017a)

The study furthermore used convenience sampling which allowed for the selection of respondents from a relatively homogenous population that were available and willing to participate at the time of data collection (Saunders, Lewis \& Thornhill, 2007). Triangulation technique was used to determine points of similarities and variations in qualitative data collected from participants through questionnaires, interviews and related literature reviews to improve the credibility of findings and interpretations.

Data was collected between July 2017 and July 2018. The respondents were informed of the purpose of the study and requested to voluntarily sign consent of participation. This means that respondents were not forced to take part in this study, it was optional. The respondents were given a questionnaire with enough space for them to explore their understanding. After completing the questionnaire, the respondents were interviewed on supplementary questions to gain insight and clarity on their responses. Notes were taken during each interview and all discussions were recorded for further review triangulation. Participants were given more time to respond to interviews in order to validate more details. The researcher also took advantage 
of his appointment to sit on the adjudication panel for the best extension practitioners in Mpumalanga Province. Similar questions relating to sustainable agriculture were asked during adjudication. Interactions were recorded, and notes were also taken during a panel of adjudication. The researcher was also able to access all PowerPoint presentations from extension practitioners. Furthermore, the researcher was able to access the final consolidated report from all the fellow adjudicators. Finally, various relevant documents and existing literature were used to relate the outcome of the study (Downe-Wamboldt, 1992; Hsieh \& Shannon, 2005).

\section{RESULTS}

This section presents the results from 68 respondents who were interviewed. Other sources of data included documents, journal articles and other related information on sustainable agriculture in order to triangulate and give insight of the data.

\subsection{Agricultural extension approaches}

Table 1: List of agricultural extension approaches

\begin{tabular}{|c|c|}
\hline Extension approaches & Evolution \\
\hline - Transfer of technology (TOT) & $1960 \mathrm{~s}$ \\
\hline - $\quad$ Training and Visit $(\mathrm{T} \& \mathrm{~V})$ & 1970s and partly in 1980 s \\
\hline - Farming System Research (FSR) & 1970 s to 1980 s \\
\hline - Farming System Research and Extension (FSR/E) & $1980 \mathrm{~s}$ \\
\hline - $\quad$ Livelihood Approach (L) & $1990 \mathrm{~s}$ \\
\hline - Sustainable Livelihood Approach (SL) & $1990 \mathrm{~s}$ \\
\hline - Farmer First Approach (FF) & 1990s \\
\hline - $\quad$ Beyond Farmer First Approach (BFF) & $1990 \mathrm{~s}$ \\
\hline - Participatory Approach (PA) & $1990 \mathrm{~s}$ \\
\hline - Cost Sharing Approach (CS) & - \\
\hline - $\quad$ Project Approach $(\mathrm{P})$ & - \\
\hline - Farmer to Farmer Approach $(\mathrm{FtF})$ & - \\
\hline - Commodity Group Approach (CG) & - \\
\hline
\end{tabular}

This paper identifies some common extension approaches that are used in Mpumalanga Province. Extension practitioners use these approaches to convey information to farmers. Approaches are platforms or ways in which extension practitioners convey information amongst farmers that they serve. The farm visit or face to face interaction and farming system approach are the most commonly used extension approaches in Mpumalanga Province. In the farming system research approach, extension recognises the farmers' work within certain systems. This means that apart from agricultural activities, farmers have some internal and external forces that influence their decision making (Ministry of Agriculture, Mechanisation and Irrigation Development, 2010). Some respondents indicated that they prefer the farmer to farmer approach, where extension practitioners bring farmers together. Farmer to farmer approach involves farmers assisting one another through the help of extension practitioners. Farmers are likely to learn from each other's experiences. 
This paper also revealed that the majority of extension practitioners use the participatory approach which recognises that farmers are part of the decision making. In order to facilitate a successful participatory approach, the following platforms should the organised: workshops, meetings, awareness, campaigns, and training. Other information includes information and farmer days. Another successful approach involves grouping farmers according to their commodities. Commodity group approaches involve farmers who produce similar products. A good example is that of maize farmers. They relate to each other as they experience similar challenges and success about maize production. Some extension practitioners prefer to organise farmers according to farming categories. Farmers are categorised according to their scope of production, such as subsistence, small scale or commercial farmers. The need drive in approach is determined by farmers who require specific support from extension practitioners. Another approach that extension uses is the farmers' forum association where all stakeholders meet quarterly to evaluate the challenges and achievements of their projects. The study also reveals that extension practitioners make use of agricultural development committees at a ward level in order to share relevant information with farmers.

The majority of practitioners still have a preference on bottom-up extension approaches, where farmers identify the problems and seek advice from extension services. The top-down approach is fading away as most practitioners avoid using this approach. The top-down approach is a traditional transfer of technology which dictates that farmers are only recipients of technology from extension practitioners. Some extension practitioners are engaged with home or community project approaches. In this way, they consult with the traditional authorities and organise meetings with this category of farmers. As a result of the growing digital platforms, some extension practitioners prefer to utilise cellular phone conversations such as sending messages and making cellular phone or telephone calls amongst their farmers. Few extension practitioners create group charts amongst farmers in order to exchange information and challenges affecting their farming enterprise.

\subsection{Assessing farmers' livelihood}

This paper evaluates whether extension practitioners consider farmers' livelihood when providing extension services in Mpumalanga Province. All respondents indicated that they consider farmers' livelihood. The concept of livelihood comprises of the capabilities, assets and activities required for a means of living. A livelihood is sustainable when it can cope with and recover from stresses and shock, maintain or enhance its capabilities and assets, while not undermining the natural resource base (Chambers, 1994; Department for International Development (DFID), 2000; Glew et al, 1995; Heller, 2003; Misturelli \& Heffernan, 2008). The respondents indicated that farmers are heterogeneous, meaning that they differ in terms of their well-being in relation to income, education, experiences, and other baselines. Extension practitioners highlighted that livelihood assessments assist them to identify farmers' needs and also plan extension services to be rendered. Respondents declared that livelihood assessments assist to conduct themselves to the level of the farmer. They also indicated that farmers are located in different areas and this tends to direct the way farmers think and do things. However, human behaviour is one of the key factors which affects the adoption of sustainable agricultural practices which involves the level of income, education and age (Cary, Webb \& Barr, 2001).

The following statements were given by some respondents:

"Categorising farmers according to their livelihood assist with planning of extension programs. Livelihood goes hand in hand with the bottom-up extension approach which 
promotes that farmers should identify their challenges and look for advice from extension services. Farmers feel happy when they are involved in every step of their projects."

"That is the first thing I consider before assisting farmers, I do situation analysis. I ask for farmer's background and current situation regarding their families. I also prefer to do the actual farm visit to understand what support will be best suited for individual farmer."

Some respondents indicated that the limited resources that the department has should be channelled to the most vulnerable farmers in order to improve their livelihood. However, they also argue that assessing livelihood will assist the department to draft proper budgets as per farmers' needs in order to improve their livelihood. They emphasised some of the details to be collected as part of livelihood assessments which includes farmers' backgrounds, their age, and the language they speak. Other extension practitioners pointed out that livelihood assessment assists when farmers are drafting business plans. They will present their plan for approval by the department and budget will be allocated based on available resources. They also indicated that the rate of adoption in extension services or innovations differs depending on farmers' livelihood.

Extension practitioners indicated that consideration of livelihood helps them to evaluate whether they are achieving their goals and objectives. Livelihood assessment assists the department to allocate resources according to farmers' needs. Practitioners will therefore develop a database for allocation of inputs such as seeds, fertilizers and mechanisation. A database on livelihood assessment is a detailed questionnaire which contains farmers' information. The practitioners highlighted that farmers are content when their livelihood is considered as resources will be allocated according to their farming categories. The challenge is that some farmers tend to provide incorrect information about their livelihood especially relating to financial statements. When farmers' livelihood is improved their farms tend to be sustainable due to positive contributions.

"It is advisable to include farmers when making decisions. Livelihood assessments assist us as extension practitioners to render an extension service that is relevant in accordance with specific commodity. I organise meetings, farmers' days and also invite farmers who already succeeded in farming."

\subsection{Knowledge of sustainable agriculture}

This section reflects on public extension practitioners in Mpumalanga Province towards their knowledge of sustainable agriculture. This section focuses on the definition of sustainable agriculture and on how extension practitioners acquired such knowledge. The respondents indicated that sustainable agriculture involves focusing on farming practices where farmers are taking care of the natural environment (Altieri, 1995; Hobbs et al, 2007; Martin \& Sauerborn, 2013). In this way, the land is protected from degradation and avoids pollution of the atmosphere. This is further supported by Mutoko (2014) who argued that water, soil, atmosphere, animals and plantation are the most affected natural resources. The respondents emphasised that they always advise farmers to use animal manure as opposed to inorganic fertilizers. The integration of crops and livestock is reported to be an important factor towards improving soil fertility. This is particularly real when planting crop which improves soil 
fertility like leguminous (Iiyama, Maitima \& Kariuki, 2007). Variety of crops in one area can also improve soil control from different pests and diseases (Gautam \& Andersen, 2016). There is a strong sentiment amongst most extension practitioners that crop rotation is closely linked to sustainable agricultural. The following statements also reflect on extension practitioners' views on sustainable agriculture:

"Sustainable agriculture involves farming in sustainable way considering ecosystem and the environment. Such farming practices should provide and protect human health, environment and animal welfare."

"To me sustainable agriculture is all about meeting societal food needs and also use methods that reserve the ability of future generation to meet their needs e.g. maintaining soil health, minimum water use, lower pollution levels, economic profitability and social equity."

"Sustainable agriculture encourages farm productivities that will produce good return for an extended period using similar resources and without depleting the natural environment. It should protect human health and also improves soil microbial activities."

The respondents pointed out that sustainable agriculture recognises the practice of Integrated Pest Management (IPM). IPM promotes the use of different methods for controlling pests (Blackshaw et al, 2001; Caamal-Maldonado et al, 2001; Inderjit, Kaur \& Foy, 2001). If farmers alternate different methods, it will avoid the frequency of solely depending on chemical pesticides and herbicides (Letourneau, 1998; Letourneau \& Bothwell, 2008; Nicholls, Parrela \& Altieri, 2001; Shennan, 2008). They further indicated that chemicals may harm beneficial species and pollute the natural environment. Other respondents maintain that minimum tillage is part of sustainable agriculture. The practice of minimum tillage has the least effect on soil compaction and erosion. A higher proportion of soil water retention can be achieved if farmers practice minimum tillage (Abid \& Lal, 2008; Karlen et al, 1998). The respondents also indicated that rotational grazing is part of sustainable agriculture. Rotational grazing prevents animals from overgrazing. Overgrazing may lead to shortage of vegetation or pastures for animals in the future. Overgrazing may also lead to soil erosion (Khwidzhili \& Worth, 2016).

This paper also highlight how the respondents acquired their knowledge for sustainable agriculture. Most of them indicated that they attended workshops on sustainable agriculture organised by the land care section within the Mpumalanga Department of Agriculture, Land and Environmental Affairs. Some knowledge was acquired through reading journal articles and documents on sustainable agriculture. A few respondents indicated they have a master's degree in sustainable agriculture acquired from universities. The majority of the respondents possess four year degrees in agriculture while some have relevant diplomas from agricultural colleges and universities of technology. Some respondents attended workshops on climate change and climate smart agriculture organised by the department. This paper also reveals that some of the respondents attended conferences, seminars, symposia and other training on sustainable agriculture. The Agricultural Development Committee (ADC) is also a platform where different stakeholders share their experiences on sustainable agriculture. The stakeholders are composed of various members depending on the location of the ADC. In most cases, the stakeholders include various government departments, municipalities, research institutes, communities, and representatives of traditional leaders. Sustainable agriculture should emerge as a result of individual or collective intelligence to maintain the long term productivity of the 
natural resources on which they depend (Pretty 1995; Rölling 1994; Sriskandarajah, Bawden \& Packham, 1991). The knowledge of respondents on the concept of sustainable agriculture is summarised in Table 2.

Table 2: Understanding pillars of sustainable agriculture

\begin{tabular}{|c|c|}
\hline & $\begin{array}{l}\text { Understanding pillars of sustainable agriculture by respondents } \\
\text { (Indicators of sustainable agricultural practices) }\end{array}$ \\
\hline $\begin{array}{l}\text { Pillar 1 } \\
\text { Maintaining } \\
\text { and increasing } \\
\text { biological } \\
\text { productivity }\end{array}$ & $\begin{array}{l}\text { - Implementation of conservation or organic farming. } \\
\text { - } \text { Farmers should avoid soil degradation and disturbance to the } \\
\text { - } \text { Natural vegetation should be protected to avoid soil erosion. } \\
\text { - Crop rotation and rotational grazing should be encouraged. } \\
\text { - Some portion of the farm should be rested (fallowing). } \\
\text { - Encourage minimum or zero tillage. } \\
\text { - Uncontaminated water should be used for irrigation. } \\
\text { - Farmers should limit or avoid the use of chemicals such as } \\
\text { - } \text { Pesticides, fungicides, inorganic fertilizers and herbicides. } \\
\text { - Mulching and making compost heap. } \\
\text { - Chemicals pollute ground water. } \\
\text { - Farmers should be encouraged to plant green manure to improve } \\
\text { - } \text { soil fertility. } \\
\text { - Proid movement of heavy machines (soil compaction). } \\
\text { - } \text { Promote microbial activity (encourage earthworms, micro-fauna }\end{array}$ \\
\hline $\begin{array}{l}\text { Pillar } 2 \\
\text { Decreasing the } \\
\text { level of the } \\
\text { risk to ensure } \\
\text { larger security }\end{array}$ & $\begin{array}{l}\text { - Planting date for farmers no longer predictable as a result of } \\
\text { climate change. } \\
\text { - Theft in farms. } \\
\text { - Natural disasters and man-maid farmers. } \\
\text { - Financial risk associated with high cost of chemicals and other } \\
\text { farm inputs. } \\
\text { - Market risk associated with competition amongst farmers in } \\
\text { - } \text { relation to quality farm produce. } \\
\text { - Choosing resistance or adaptable cultivars. } \\
\text { - Planting of certified seeds. } \\
\text { - Continuous training of both extension and farmers. } \\
\text { - Linking farmers with formal markets, logistical support, agro- } \\
\text { - Processing and other market hubs. } \\
\text { - Cost-harvest risk (storage and handling). } \\
\text { - Planting in controlled environment (considers both plastic and } \\
\text { - } \text { shade tunnels). } \\
\text { - Farmers should have insurances for their farm and produce. } \\
\text { Farmers should guard against disease outbreaks for animals. }\end{array}$ \\
\hline
\end{tabular}




\begin{tabular}{|c|c|}
\hline & $\begin{array}{l}\text { - Labour unrest (strikes) and pickets. } \\
\text { - Farmers should have proper fences in their farms. }\end{array}$ \\
\hline $\begin{array}{l}\text { Pillar } 3 \\
\text { Protecting the } \\
\text { quality of } \\
\text { natural } \\
\text { resources }\end{array}$ & $\begin{array}{l}\text { - Rainwater harvesting. } \\
\text { - Training is required for administration and safe keeping of } \\
\text { agricultural chemicals. } \\
\text { - Farmers should be encouraged to use irrigation systems that save } \\
\text { water. } \\
\text { - Farmers should avoid the spraying of chemicals which pollute the } \\
\text { atmosphere. } \\
\text { - Climate smart agriculture. } \\
\text { - Biological control of pests. } \\
\text { - Protection of beneficial insects such as bees and ladybirds. } \\
\text { - Intercropping with repellents or herbs to avoid the use of } \\
\text { - } \text { - Integrated pest management. } \\
\text { - Chemicals pollute rivers and dams (pose danger on aquatic life). }\end{array}$ \\
\hline $\begin{array}{l}\text { Pillar } 4 \\
\text { Ensuring } \\
\text { agricultural } \\
\text { production is } \\
\text { economically } \\
\text { viable }\end{array}$ & $\begin{array}{l}\text { - Farmers produce for commercial purpose. } \\
\text { - Farmers should know budgeting processes and planning (clear } \\
\text { - } \text { Price of farm inputs and inflation. } \\
\text { - Production should be above break-even point. } \\
\text { - Efficient record keeping. } \\
\text { - Good profit without harming the natural environment. } \\
\text { - Farmers should make money (profit) from farming practices. } \\
\text { - Farmers should be encouraged to invest their profit. } \\
\text { - Increased production in farms. }\end{array}$ \\
\hline $\begin{array}{l}\text { Pillar } 5 \\
\text { Ensuring } \\
\text { agricultural } \\
\text { production is } \\
\text { socially } \\
\text { acceptable }\end{array}$ & $\begin{array}{l}\text { - Farmers produce for own consumption. } \\
\text { - Farmers avoid the production of genetically modified organisms. } \\
\text { - Farmers should produce products that are acceptable by } \\
\text { - } \text { Fonsumers (Products should not have health issues). } \\
\text { - Farmers should form cooperatives and relevant forums. }\end{array}$ \\
\hline
\end{tabular}

Adapted from Khwidzhili and Worth (2017b)

\subsection{Promoting sustainable agriculture}

The respondents were asked which role public agricultural extension could play in promoting sustainable agriculture. They indicated that farmers should be trained on conservation farming. In conservation farming, the soil is less disturbed by tractors. Farmers should be encouraged to produce products that are accepted to the market. Farmers should be taught using practical demonstration rather than theory. The respondents indicated that farmers should be encouraged to use environmentally friendly inputs such as organic fertilizers and other safe production inputs; this assertion is confirmed by Shah, Ganji and Coutroubis (2017). The innovation should first be tested or researched and thereafter be shared with farmers. Other respondents proposed for coordinated resource management. Coordination of agricultural resources will help facilitate farmers to use inputs that are not harmful to the natural environment (Food and Agriculture Organisation of the United Nations (FAO), 2014; Kassie et al, 2009; Krall, 2015). 
Extension practitioners should organise workshops and awareness committees on sustainable agriculture. Farmers should be encouraged to form partnerships with other farmers in order to discuss and share expertise of sustainable agricultural practices. Cary et al (2001) argued that sustainable agricultural practices differ with the environment as there is no specific practice for all users. They indicated that there should be an introduction of farmers' training centres within the province (Mpumalanga). The respondents proposed that participatory and bottom-up extension approaches should be emphasised, as these approaches make farmers part of problem solving and decision making.

The respondents were further asked if they would encourage other extension practitioners to promote sustainable agriculture. All respondents indicated they will encourage sustainable agricultural practices to prevent further degradation of the natural environment. Farmers are likely to adopt agricultural advice if they know such innovation has worked for other farmers. There is no single extension approach that will suit all occasions. This means that extension approaches should the used alternately depending on categories of farmers. Some views about the promotion of sustainable agriculture are:

"Yes, I encourage others to promote sustainable agriculture because agriculture depends on scarce natural resources such as water, soil and the ecosystem. Therefore, it is critical that all agricultural producers should practice sustainable agriculture."

"Yes, because this is for the benefit of farmers who are poor and living in rural areas. These farmers can't afford food without farming. Farming helps them produce food and generate income. Extension should assist farmers produce more wood without harm to the natural environment."

"Yes, we must remember that we are not only doing for farmers but also for the future generation of farmers. Farmers should take care of the natural environment and not forgetting that farmers should still get good return from their produce."

"Definitely, since extension officers have high influence towards farmers. Farmers will be able to move from conventional to conservation agriculture. In conservation agriculture farmers will save water and practice minimum tillage."

\subsection{Supporting extension practitioners towards sustainable agriculture}

Respondents were asked what kind of support they will require from their managers to promote sustainable agriculture. Most respondents highlighted that they require regular training and workshops on sustainable agriculture. They pointed out that managers should approve both weekly and monthly itineraries so that they can attend farm visits, workshops and campaigns. There should be intervention from the National Department of Agriculture, Forestry and Fisheries, and the Agricultural Research Council (ARC). Some respondents indicated they still need further formal training within an institution of higher learning such as Technical Vocational Education Training (TVET) colleges, colleges of agriculture, universities, and universities of technologies.

"I require more training, workshops, exposure, farm visit and even more. This can assist our farmers and extension services to understand and contribute towards sustainable agriculture. Trainings can also help extension practitioners understand 
some risk that affects farmers. Extension service will help disseminates information and mitigation of risk and disasters."

Most respondents indicated that there is no support provided from their manager in order to support sustainable agriculture. They suggested that any information from other districts should be shared amongst officials. The support will assist the practitioners to relate the information that they provide to farmers. Most extension practitioners have subsidy cars or government vehicles that they use when providing extension services. Other tools include cellular phones, laptops, and other gadgets that assist them to provide extension services. There are also programmes such as extension apps (applications) and extension suite online which assist the practitioners with information that assists farmers. The respondents also revealed that most extension managers visit projects in order to monitor if they are providing services to farmers.

"My manager gives me contact for different stakeholders so that we share information on sustainable agriculture."

'The manager is responsible for both production and administrative policies. This makes it difficult to focus on sustainable agriculture. The support given is general and not specific to sustainable agriculture."

"No support I get from my manager except that she travels a lot to claim fuel from the department and not monitor work done. Extension manager often spoil farmers by giving production inputs instead of farmers buying inputs for themselves."

\subsection{Reaction of farmers towards sustainable agriculture}

In response to the pressure for food production to meet the demand of the ever-growing world population, many farmers have resorted to using farming practices that increase agricultural production without considering the potential harm to the natural environment (Khwidzhili \& Worth, 2017b). Respondents were asked the following question: What is the reaction of farmers as you advise them about the importance of sustainable agriculture?

Respondents acknowledged that farmers are positive about sustainable agricultural practices especially in response to the zero tillage method. In zero tillage, less soil is disturbed by machinery. The respondents indicated that farmers are willing to reduce their stocking order to avoid overgrazing. Overgrazing exposes soil to erosion. There is some resistance by farmers who perceive sustainable agricultural practices as unprofitable. Farmers are comfortable to use irrigation systems that save water and other practices such as water harvesting. Farmers replace chemical fertilizers with animal manure.

"Most smallholder farmers have challenges with access to market. The engagement that I always have with farmers is on compliance to good practice (sustainable agriculture). The compliance helps with market access certification. The reaction of farmers is always positive because sustainable agricultural practices help in accessing markets."

This paper noted that most commercial farmers are money-driven and therefore it is difficult for them to practice sustainable agriculture. However, there is an indication that farmers are gradually moving towards adopting sustainable agricultural practices. This is as a result of the fact that farmers have noticed continuous decline of the natural resources. In most 
circumstances, farmers are interested in increasing yield without considering the natural environment. Farmers require more land for agricultural purpose in order to farm for markets. Even though awareness of these practices to the rightful people may be considered inadequate to promote adoption, some farmers have reported to not adopt sustainable agricultural practices even when they are aware of them (Rodriguez et al, 2009).

"Farmers respond very well on taking care of natural resource because we do advise them that if they don't protect it, they will lose their treasure. This can be witness when we are visiting their farms. Farmers have made gabions to prevent soil erosion. They also construct some waterways and build earth dams to store water. Other farmers bought some water tanks to store water and also use drip irrigation systems to prevent waste of water."

A study by Alonge and Martin (1995) argued about different barriers which influence the level of adoption by farmers. Among these barriers are human behaviour and their perception towards the sustainable agriculture as well as resources as means to adopt the practices.

\subsection{Initiatives for promoting sustainable agriculture in Mpumalanga Province}

Respondents were asked what measures should be in place to promote sustainable agriculture in Mpumalanga Province. They suggested that the Department of Agriculture, Rural Development, Land and Environmental Affairs (DARDLEA) should partner with relevant stakeholder to create awareness on sustainable agriculture. Most respondents indicated that more training, workshops and dialogues should be organised to promote sustainable agriculture. It is imperative that workshops on sustainable agriculture be prioritised in order to improve the knowledge on the subject. Knowledge on sustainable agriculture is important in compliance with market access certification such as South African Good Agricultural Practice (SAGAP). The lack of knowledge among the extension practitioners is that they do not receive any training in the service they provide. They also neglect the research findings, which carry the scientific findings of the sustainable agriculture (Agunga \& Igodan, 2007). Lack of information by the change agents can also affect the distribution of practices to the farmers.

Some respondents indicated that institutions of higher learning, especially the University of Mpumalanga, should introduce formal courses and short courses on sustainable agriculture. In support of institutions of higher learning, sustainable agricultural practices should be initiated in foundation education systems. The respondents indicated that there should be a departmental grant dedicated to farmers who are already practicing sustainable agriculture. This will encourage many smallholder farmers to engage in sustainable agricultural practices. Farmers should be provided with resources that promote sustainable agricultural practices.

"There should be adequate provision of budget available to purchase no till implements especially for smallholder farmers. On-farm training and demonstration should be emphasised. Pezukwemkhono and other departmental programmes should be designed to promote sustainable agricultural practices."

Most respondents proposed that there should be forums that are targeting farmers who are practicing sustainable agriculture. They proposed that the department should formalise forums for relevant stakeholders that will meet to promote and share ideas on sustainable agricultural 
practices. Departmental programmes of mechanisation should support or prioritise implements that promote sustainable agricultural practices at a farm level.

\section{CONCLUSION AND RECOMMENDATIONS}

The study found that extension practitioners in Mpumalanga are not aware of the five pillars of sustainable agriculture. However, the responses suggest that they fully understand the three common pillars of sustainability which are economic, social, and environmental viability. There is a need to define all five pillars of sustainability in their totality. The study reveals that there are no frameworks or guideline documents supporting sustainable agriculture in Mpumalanga Province. This might be as a result of South Africa not having an inclusive policy on sustainable agricultural practices (Khwidzhili \& Worth, 2017b).

The study shows that the extension practitioners in Mpumalanga are aware of the concept of sustainable livelihood and that it is imperative to consider and understand farmers' backgrounds prior to providing extension services. The study also discovered that the promotion of sustainable agricultural practices is dependent on the knowledge of individual extension practitioners. This is dictated by the level of education and experience on the concept of sustainable agriculture. There are no clear benchmarks or targets in place towards promotion of sustainable agricultural practices in Mpumalanga Province. The study further revealed that there is formal support towards promoting sustainable agriculture. There is a conflicting argument amongst farmers who support sustainable agriculture and those against the concept. Most farmers prefer to take care of their natural resources in order to conserve it for future generations. The latter argument is based on the fact that sustainable agricultural practices are not practically income-orientated.

There is a need for training of extension practitioners on the five pillared framework of sustainability. There is also a need to establish a sub-directorate that will focus on sustainable agriculture in Mpumalanga. Finally, potential future studies should be conducted to further categorise sustainable agricultural practices according to the five pillars in sustainable agriculture.

\section{REFERENCES}

ABID, M. \& LAL, R., 2008. Tillige and drainage impact on soil quality: Aggregate stability, carbon and nitrogen pool. Soil Tillage Res., 100(1-2):89-98.

AGUNGA, R. \& IGODAN, C., 2007. Organic farmers' need and attitudes towards extension. J. Ext., 45(6):1-9.

ALONGE, A.J. \& MARTIN, R.A., 1995. Assessment of the adoption of sustainable agriculture practices: Implications for agricultural education. J. Agric. Educ., 36(3):34-42.

ALTIERI, M.A., 1995. Agroecology: The science of sustainable agriculture. 2nd ed. New York: CRC Press.

BLACKSHAW, R.E., MOYER, J.R., DORAN, R.C. \& BOSWELL, A.L., 2001. Yellow Sweetclover, green manuring, and its residues effectively suppress weeds during fallow. Weed Sci., 49(3):406-413. 
CAAMAL-MALDONADO, J.A., JIMÈNEZ-OSORNIO, J.J., TORRES-BARRAGAN, A. \& ANAYA, A.L., 2001. The use of allelopathic legumes cover and mulch species for weed control in cropping systems. Agron. J., 93(1):27-36.

CARY, J., WEBB, T. \& BARR, N., 2001. The adoption of sustainable practices: Some new insights. An analysis of drivers and constraints for the adoption of sustainable practices derived from research. Land \& Water Report. Canberra, Australia.

CHAMBERS, R., 1994. The origins and practice of participatory rural appraisal. World Dev., 22(7):953-969.

COHEN, L., MANION, L. \& MORRISON, K., 2007. Research methods in education. 6th ed. London: Routledge.

DEPARTMENT FOR INTERNATIONAL DEVELOPMENT (DFID), 2000. Sustainable livelihoods guidance sheets. London, England.

DOWNE-WAMBOLDT, B., 1992. Content analysis: Method, applications and issues. Health Care Women Int., 13(3):313-321.

FOOD AND AGRICULTURE ORGANISATION OF THE UNITED NATIONS (FAO), 2014. Building a common vision for sustainable food and agriculture. Rome, Italy.

GAUTAM, Y. \& ANDERSEN, P., 2016. Rural livelihood diversification and household wellbeing: Insights from Humla, Nepal. J. Rural Stud., 44:239-249.

GLEW, D.J.O., O’LEARY-KELLY, A.M., GRIFFIN, R.W. \& VAN FLEET, D.D., 1995. Participation in organizations: A preview of the issues and proposed framework for future analysis. J. Manag., 21(3):395-421.

HELLER, F., 2003. Participation and power: A critical assessment. Appl. Psychol., 52(1):144163.

HOBBS, R.P., SAYRE, K. \& GUPTA, R., 2007. The Role of conservation agriculture in sustainable agriculture. Philos. Trans. R. Soc. Lond. B. Biol. Sci., 363(1491):543-555.

HSIEH, H.F. \& SHANNON, S.E., 2005. Three approaches to qualitative content analysis. Qual. Health Res., 15(9):1277-1288.

IIYAMA, M., MAITIMA, J. \& KARIUKI, P., 2007. Crop-livestock diversification patterns in relation to income and manure use: A case study from a Rift Valley Community, Kenya. Afr. J. Agric. Res., 2(3):58-66.

INDERRJIT, M., KAUR, M. \& FOY, C.L., 2001. On the significance of field studies in allelophaty. Weed Technol., 15(4):792-797.

KARLEN, D.L., KUMAR, A., KANWAR, R.S., CAMBARDELLA, C.A. \& COLVIN, T.S., 1998. Tillage system effects on 15-year carbon base and stimulated $\mathrm{N}$ budget in a tile drained Iowa field. Soil Tillage Res., 48(3):155-165.

KASSIE, M., ZIKHALI, P., PENDER, J. \& KÖHLIN, G., 2009. Sustainable agricultural practices and agricultural productivity in Ethiopia: Does agroecology matter? Department of Economics Working Paper 406. University of Gothenburg, Sweden.

KHWIDZHILI, R.H. \& WORTH, S.H., 2016. The sustainable agriculture imperative: Implications for South African agricultural extension. S. Afr. J. Agric. Ext., 44(2):19-29. 
KHWIDZHILI, R.H. \& WORTH, S.H., 2017a. Evaluation of policies promoting sustainable agriculture in South Africa. S. Afr. J. Agric. Ext., 45(2):73-85.

KHWIDZHILI, R.H. \& WORTH, S.H., 2017b. The sustainable agricultural imperative: Implications for South African extension. Presented to the Young Scientists Conference. Vienna, Austria.

KHWIDZHILI, R.H. \& WORTH, S., 2019. Evaluation of South Africa's public agricultural extension in the context of sustainable agriculture. S. Afr. J. Agric. Ext., 47(1):20-35.

KRALL, S., 2015. What is sustainable agriculture? Available from: www.giz.de/nachhaltigelandwirtschaft

LETOURNEAU, D.K., 1998. Conserving biology, lessons for conserving natural enemies. In Conservation Biology Control (pp.9-38). Carlifonia: Academic Press.

LETOURNEAU, D.K. \& BOTHWELL, S.G., 2008. Comparison of organic and conventional farms: Challenging ecologists to make biodiversity functional. Front. Ecol. Environ., 6(8):430-438.

MARTIN, K. \& SAUERBORN, J., 2013. Agroecology. Amsterdam: Springer.

MINISTRY OF AGRICULTURE, MECHANISATION AND IRRIGATION DEVELOPMENT, 2010. Participatory Extension Approaches (PEA) in Zimbabwe. Harare, Zimbabwe.

MISTURELLI, F. \& HEFFERNAN, C., 2008. What is poverty? A diachronic exploration of the discourse on poverty from the 1970s to the 2000s. Eur. J. Dev. Res., 20(4):666-684.

MUTOKO, M.C., 2014. Adoption of climate-smart agricultural practices: Barriers, incentives, benefits and lessons learnt from the MICCA pilot site in Kenya. FAO. Rome, Italy.

NICHOLLS, C.I., PARRELA, M. \& ALTIERI, M.A., 2001. The effect of vegetational corridor on the abundance and dispersal of insect biodiversity within Northern California organic vineyard. Landsc. Ecol., 16(2):133-146.

NIEUWENHUIS, J., 2007. Qualitative research methods and data gathering techniques. In First step in research (pp.69-97). Pretoria: Van Schaik Publishers.

PRETTY, J.N., 1995. Regenerating agriculture: Policies and practice for sustainability and self-reliance. London: Earthscan Publications.

RODRIGUEZ, J.M., MOLNA, J.J., FAZIO, R.A., SYDNOR, E. \& LOWE, M.J., 2009. Barriers to adoption of sustainable agriculture practices: Change agent perspectives. Renew. Agr. Food Sys., 24(1):60-71.

RÖLLING, N., 1994. Platfoms for decision making about ecosystem. In The future of the land (pp.385-394). Chichester: John Wiley \& Sons.

SAUNDERS, M., LEWIS, P. \& THORNHILL, A., 2007. Research methods for business students. 4th ed. Harlow: Prentice Hall.

SHAH, S., GANJI, E.N. \& COUTROUBIS, A., 2017. Evaluation of sustainable practices within project management methods sustainability \& social. Available from: https://gala.gre.ac.uk/id/eprint/16645/13/16645\%20SHAH_Evaluation_of_Sustainable Practices_\%280A\%29_2017.pdf 
SHENNAN, C., 2008. Biotic interactions, ecological knowledge and agriculture. Philos. Trans. R. Soc. Lond. B. Biol. Sci., 367(1492):717-739.

SRISKANDARAJAH, N., BAWDEN, R.J. \& PACKHAM, R.G., 1991. System agriculture: Aparadigm for sustainability. AFSRE Newsletter, 2(2):1-5.

TEY, Y.S., LI, E., BRUWER, J., ABDULLAH, A.M., CUMMINS, J., RADAM, A., ISMAIL, M.M. \& DARHAM, S., 2012. Refining the definition of sustainable agriculture: An inclusive perspective from Malaysian vegetable sector. Int. J. Sci. Technol., 6(3):379396.

SILVERMAN, D., 2010. Doing qualitative research. 3rd ed. London: Sage. 
